\title{
PENGARUH GAYA KEPEMIMPINAN TERHADAP KINERJA KARYAWAN PADA PT. DIGITAL MEDIA ASIA JAKARTA SELATAN
}

\author{
Gamar Ariyanto, S.Sos., M.Si \\ Universitas Mitra Karya \\ ariyanto@umika.ac.id
}

\begin{abstract}
Penelitian ini bertujuan mengetahui dan menganalisis pengaruh gaya kepemimpinan terhadap kinerja karyawan pada PT. Digital Media Asia Jakarta Selatan, Penelitian ini dilakukan terhadap 35 orang karyawan PT. Digital Media Asia Jakarta Selatan yang menjadi responden, Metode penelitian yang digunakan dalam penelitian ini yaitu metode deskriptif dengan pengumpulan data melalui wawancara, observasi dan pembagian questioner pada karyawan PT. Digital Media Asia Jakarta selatan.

Kinerja karyawan merupakan faktor penting dalam perusahaan, karena dapat menentukan berkembang tidaknya suatu perusahaan. Kepemimpinan adalah cara seorang pemimpin dalam mempengaruhi perilaku bawahannya,agar mau bekerjasama dan produktif demi tercapainya suatu tujuan dari suatu organisasi maupun suatu lembaga. konsep kepemimpinan lebih merupakan suatu motivasi yang dapat memicu inspirasi kepada bawahannya.jika ingin meningkatkan kinerja pegawai perlu memahami beberapa faktor-faktor yang dapat mempengaruhi motivasi kerja pegawai. Instrumen penelitian diuji dengan uji validitas dan reliabilitas, analisis data menggunakan regresi linear sederhana, pengujian hipotesis menggunakan koefisien determinasi dan uji parsial, data diolah dengan SPSS versi 25. Hasil penelitian ini menunjukkan bahwa gaya kepemimpinan berpengaruh positif dan signifikan terhadap kinerja karyawan PT. Digital Media Asia Jakarta Selatan.
\end{abstract}

Keyword : gaya kepemimpinan, kinerja karyawan

\section{PENDAHULUAN}

Dalam perkembangan zaman modern saat ini, berbagai macam aspek keunggulan dibutuhkan oleh setiap organisasi dalam rangka mencapai tujuannya. Faktor utama yang dibutuhkan dalam rangka mewujudkan harapan organisasi tersebut adalah faktor sumber daya manusia.
Setiap organisasi atau perusahaan diharapkan mampu mengelola dan mengatur aspek sumber daya manusia yang dimilikinya dengan sebaik mungkin. Karena dengan terkelolanya faktor sentral ini melalui manajemen sumber daya manusia yang baik, tujuan dan cita-cita perusahaan akan dapat tercapai. Manajemen sumber daya manusia merupakan sarana untuk 
meningkatkan kualitas manusia dengan upaya memperbaiki sumber daya manusia, meningkatkan kinerja dan daya hasil organisasi, sehingga dapat mewujudkan karyawan yang memiliki disiplin dan kinerja yang tinggi.

Gaya kepemimpinan merupakan norma atau perilaku yang digunakan oleh seseorang pada saat orang tersebut mencoba mempengaruhi perilaku orang lain seperti yang ia lihat, Thoha (2013:49). Berdasarkan hasil observasi yang dilakukan oleh peneliti dengan salah satu karyawan PT. Digital Media Asia Jakarta Selatan, bahwa terdapat suatu keberhasilan kinerja para karyawan yang didukung oleh adanya pengaruh kepemimpinan yang baik. Pernyataan dari karyawan PT. Digital Media Asia Jakarta Selatan tersebut menunjukkan adanya permasalahan yang terkait dengan gaya kepemimpinan yang kurang baik. Dimana sosok kepemimpinan manager dalam memimpin para karyawan selama ini kurang baik terutama pada pola komunikasi yang tidak jelas yang membuat para karyawan PT. Digital Media Asia Jakarta Selatan salah mengartikan apa yang diperintahkannya.
Untuk itu gaya kepemimpinan yang baik harus diterapkan kepada bawahannya agar dapat menghasilkan pekerjaan karyawan PT. Digital Media Asia Jakarta Selatan sesuai dengan tanggung jawabnya. Hal ini dapat dilihat dalam kehadiran karyawan tabel berikut:

Gambar Grafik 1.1

Tingkat Absensi Karyawan PT. Digital Media Asia Tahun 2018

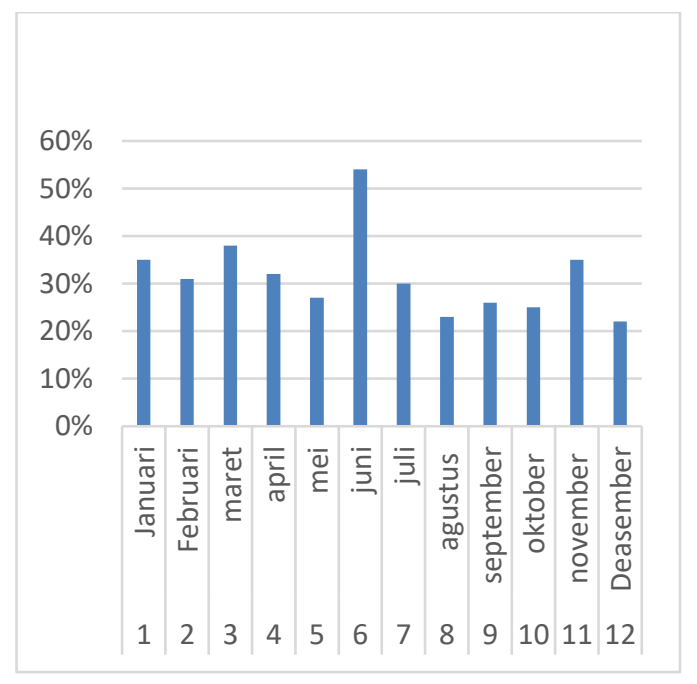

Sumber PT. Digital Media Asia Tahun 2019

Berdasarkan gambar grafik 1.1, tingkat kehadiran karyawan PT. Digital Media Asia dalam kurun satu tahun sangat fluktuatif tetapi cenderung mengalami penurunan. Kehadiran para karyawan tidak pernah mencapai lebih dari $60 \%$ melainkan hanya di bulan Juni mencapai 54\%. Akibat dari tingkat 
kehadiran yang rendah maka kinerja karyawan PT. Digital Media Asia juga mengalami penurunan. Tingkat kehadiran karyawan PT. Digital Media Asia yang rendah disebabkan karena kurangnya motivasi dari pimpinan dan gaya kepemimpinannya yang kurang baik sehingga karyawan merasa kurang nyaman dalam bekerja.

Tujuan penelitian ini adalah sebagai berikut :

1. Untuk mengetahui pengaruh gaya kepemimpinan berpengaruh terhadap kinerja karyawan pada PT. Digital Media Asia Jakarta Selatan.

2. Untuk mengetahui pengaruh gaya kepemimpinan berhubungan terhadap kinerja karyawan pada PT. Digital Media Asia Jakarta Selatan.

\section{Hipotesis}

H1. Diduga ada hubungan antara gaya kepemimpinan dengan kinerja karyawan pada PT. Digital Media Asia. H2. Diduga ada pengaruh antara gaya kepemimpinan dengan kinerja karyawan pada PT. Digital Media Asia.

\section{Kajian-Kajian Terdahulu}

Bryan Johannes Tampi pada tahun (2014) yang berjudul Pengaruh kepemimpinan dan Motivasi terhadap kinerja karyawan pada PT Bank Negara Indonesia, Tbk ( Regional Sales Manado ). Metode kuantitatif uji T bahwa gaya kepemimpinan dan motivasi berpengaruh positif dan signifikan terhadap kinerja karyawan. Hasil penelitian secara simultan dengan menggunakan $\mathrm{F}$, menunjukkan bahwa semua variable bebas pengaruh secara signifikan terhadap kinerja karyawan.

Flora Valentina pada tahun (2015) yang berjudul Pengaruh kepemimpinan dan budaya organisasi terhadap kinerja karyawan pada PT Honda cikarang. Metode kuantitatif Hasil analisis regresi linier berganda diperoleh bahwa faktor yang paling dominan berpengaruh terhadap kinerja karyawan adalah budaya organisasi. hal ini dibuktikan dengan nilai standardized coeffficient yang terbesar. budaya organisasi berpengaruh secara positif dan signifikan terhadap kinerja karyawan. semakin baik budaqya organisasi, maka kinerja karyawan akan meningkat. gaya kepemimpinan 
berpengaruh positif terhadap kinerja karyawan, artinya apabila gaya kepemimpinan semakin baik, maka kinerja karyawan akan meningkat.

Banter Adis Munandar pada tahun (2018) Mahasiswa STIE TRIBUANA yang berjudul Pengaruh gaya kepemimpinan terhadap kinerja karyawan pada Pt. Adira dinamika multifinance cabang bekasi. Metode kuantitatif Dengan hasil bahwa terdapat pengaruh gaya kepemimpinan terhadap kinerja karyawan, dengan nilai yang signifikan sebesar 0,000 lebih kecil dari 0,05 maka dikatakan bahwa terdapat pengaruh antara variable bebas terhadap variable terikat secara parsial.

\section{METODOLOGI PENELITIAN} Deskripsi Operasional Variabel

Menurut Sugiyono (2012:38) deskriptif variabel adalah suatu atribut atau sifat atau nilai dari orang, objek atau kegiatan yang mempunyai variasi tertentu yang ditetapkan oleh peneliti untuk dipelajari dan kemudian ditarik kesimpulannya. Dalam penelitian ini, terdapat dua variabel penelitian yang digunakan yaitu:
Gaya kepemimpinan (X), variable independent (variabel bebas). independent variable $(\mathrm{X})$ adalah variabel bebas yang artinya mempengaruhi variabel (Y).

Kinerja karyawan (Y) variabel dependent (variabel terikat). Dependent variable (Y) adalah variabel terikat yang artinya variabel yang dipengaruhi oleh variabel sebelumya atau variabel (X).

\section{Tempat Penelitian}

Penelitian ini dilaksanakan di PT. Digital Media Asia. Yang beralamat The Convergence Indonesia JL. HR. Rasuna Said, Setia Budi Kuningan Jakarta Selatan, DKI Jakarta.

\section{Tahapan Penelitian}

Waktu penelitian ini dilaksanakan selama 90 hari di mulai dari Bulan November 2019 sampai bulan Februari 2020.

\section{Populasi Dan Sampel}

Dalam penelitian ini sampel yang digunakan adalah keseluruhan jumlah karyawan yang ada di PT. Digital Media Asia Jakarta Selatan yakni yang berjumlah 37 orang. Dikarenakan terlalu sedikit untuk di ambil sampel.

Sedangkan sampel, menurut Sugiyono (2010:116) adalah bagian dari 
jumlah dan karakteristik yang dimiliki oleh populasi tersebut. Dikarenakan populasi dalam penelitian ini hanya 35 orang terlalu sedikit jika ditarik sampel. Maka sampel dalam penelitian ini diambil dari keseluruhan jumlah karyawan PT. Digital Media Asia Jakarta Selatan.

Sumber Data

$$
\text { Dalam penelitian ini }
$$
menggunakan sumber data berupa data primer dan data sekunder. Data primer dalam penelitian ini berupa wawancara langsung ke karyawan PT. Digital Media Asia Jakarta Selatan dan membagikan kuestioner online kepada karyawan PT. Digital Media Asia Jakarta Selatan. Dan data sekunder dalam penelitian ini adalah data yang diperoleh dari PT. Digital Media Asia, absensi karyawan, Struktur organisasi dan sejarah yang terdapat dalam dokumen karyawan PT. Digital Media Asia Jakarta Selatan.

Teknik pengumpulan data dalam penelitian ini adalah :

Teknik kuesioner, yaitu teknik pengumpulan data yang dilakukan dengan cara memberi seperangkat pertanyaan ataupun pernyataan tertulis kepada responden untuk dijawab,
Sugiyono (2013:199). Dalam penelitian ini membagikan kuesioner kepada seluruh karyawan PT. Digital Media Asia yang berjumlah 35 orang.

Teknik wawancara, yakni teknik dengan mengajukan pertanyaan secara langsung melalui tatap muka yang dilakukan pengumpul data kepada instansi terkait, Arikunto (2013:199). Dalam penelitian ini dilakukan wawancara secara langsung dengan mewawancarai kayawan PT. Digital Media Asia Jakarta Selatan.

Teknik observasi, yakni kegiatan pemuatan penelitian terhadap suatu objek, Sugiyono (2015:204). Dalam penelitian ini dilakukan dengan mendatangi langsung ke karyawan PT. Digital Media Asia Jakarta Selatan yang dilakukan pada bulan November 2019 sampai bulan Februari 2020.

Teknik dokumentasi, yaitu cara yang dilakukan untuk memperoleh data dan informasi dalam bentuk buku, arsip, dokumen, tulisan angka dan gambar yang berupa laporan serta keterangan yang dapat mendukung penelitian, Sugiyono (2015:329). Dalam penelitian ini teknik dokumentasi yang dilakukan adalah dengan melihat secara langsung 
arsip pada PT. Digital Media Asia Jakarta Selatan, berupa jumlah struktur organisasi.

\section{HASIL DAN PEMBAHASAN}

PT. Digital Media Asia adalah perusahaan yang melaksanakan berbagai kegiatan-kegiatan dalam bidang yang berkaitan dengan iklan dan marketing yang berlndaskan kreativitas profesionalisme dan kompetensinya, kami yakin dapat berperan dalam menciptakan karya-karya dan kegiatankegiatan yng bernilai di bidangnya dan dapat memberikan kontribusi kepada masyarakat. Jumlah klien yang puas dengan kinerja kami terus bertambah, serta mempunyai harapan yang besar untuk dapat terus sukses melayani mereka.

\section{Uji Instrumen}

Instrumen yang digunakan dalam penelitian ini adalah kuesioner yang dapat memberikan data atribut yang membentuk kesiapan pada tingkat individu. Dalam penelitian ini saya menggunakan skala likert untuk mengetahui hasil kuesioner. Skala likert adalah digunakan untuk mengukur sikap, pendapat, dan persepsi seseorang atau sekelompok orang tentang fenomena social. Dalam penelitian, fenomena sosial ini telah ditetapkan secara spesifik oleh peneliti, yang selanjutnya disebut sebagai variabel penelitian.

Dengan skala likert maka variabel yang akan diukur dijabarkan menjadi indikaror variabel. Kemudian indikator tersebut dijadikan sebagai titik tolak untuk menyusun item instrumen yang dapat berupa pernyataan atau pertanyaan Sugiyono (2016:93). Jawaban setiap item instrumen yang menggunakan skala likert mempunyai gradasi dari sangat positif sampai sangat negatif, yang dapat berupa kata antara lain :

\section{Uji Validitas}

Uji validitas mampu mengungkapkan sesuatu yang akan diukur oleh kuesioner tersebut. Uji validitas dilakukan dengan membandingkan nilai $r$ hitung dengan nilai $r$ tabel untuk degree of feedomd $(F)$ $=\mathrm{n}-2$ dengan alpha 005. Jika $\mathrm{r}$ itung lebih besar dari $r$ tabel dan $r$ positif, maka butir atau pertanyaan tersebut dikatakan valid. Untuk pengujian validitas instrumen dalam penelitian ini menggunakan rumus korelasi sebagai berikut : Ghozali 
(2011:53) mengemukakan uji validitas digunakan untuk mengukur sah atau tidaknya suatu kuesioner.

Dalam pengujian validitas instrument menggunakan rumus korelasi product momen untuk mengetahui antara skor butir (X) dengan skor tunggal (Y).

Jika $r$ hitung positif serta $r$ hitung $>\mathrm{r}$ tabel maka butir atau variabel tersebut valid.

Jika $r$ hitung tidak positif dan $r$ hitung $<\mathrm{r}$ tabel maka butir atau variabel tersebut tidak valid.

Uji Reliabilitas

Uji Reliabilitas adalah alat untuk mengukur suatu kuesioner yang mempunyai indikator dari variabel atau konstruk. Ghozali (2011:47) mengemukakan sebuah kuesioner dinyatakan reliabel jika jawaban seseorang terhadap pernyataan adalah konsisten atau stabil dari waktu kewaktu. Pengukuran realibilitas dapat dilakukan dengan cara:

Repeated measure atau pengukuran ulang, dalam cara ini seseorang akan diberikan pertanyaan yang sama pada waktu yang berbeda, lalu kemudian dilihat apakah responden tetap konsisten dengan jawabannya.
One shot atau pengukuran sekali saja.

Metode pengukuran hanya dilakukan sekali saja, lalu kemudian hasilnya dibandingkan dengan pertanyaanpertanyaan lain atau mengukur korelasi antar jawaban pertanyaan. Uji realibilitas ini dapat digunakan melalui program SPSS, yang akan memberikan fasilitas untuk mengukur nilai reliabilitas dengan menggunakan uji statistic cronbach alpa $(\alpha)$. Suatu konstruck atau variabel dikatakan reliabel jika memberikan nilai cronbach alpha $(\alpha)>0,60$ Ghozali (2011:48).

Uji Analisis

Metode analisis data yang digunakan dalam penelitian ini adalah uji korelasi, determinasi, regresi dan uji model regresi linier sederhana. Berikut penjelasan mengenai uji analisi dari penelitian ini :

Uji Korelasi

Uji korelasi ini digunakan untuk mengetahui kekuatan hubungan antara korelasi kedua variabel dimana variabel lainnya yang dianggap berpengaruh dikendalikan atau dibuat tetap (sebagai variabel kontrol). Karena variabel yang diteliti adalah data interval maka teknik 
statistik yang digunakan adalah pearson correlation produk moment, Sugiyono (2013:216).

Dari hasil yang diperoleh dari rumus di atas, dapat diketahui tingkat pengaruh variabel $\mathrm{x}$ dan variabel $\mathrm{y}$. pada hakikatnya nilai $r$ dapat bervariasi dari 1 hingga +1 , atau secara matematis dapat ditulis menjadi $-1<\mathrm{r}<+1$. Hasil dari perhitungan akan memberikan tiga alternatif, yaitu:

Bila $\mathrm{r}=0$ atau mendekati 0 , maka korelasi antara kedua variabel sangat lemah atau tidak terdapat hubungan antara variabel $\mathrm{x}$ terhadap variabel $\mathrm{y}$.

Bila $\mathrm{r}=+1$ atau mendekati +1 , maka korelasi antara kedua variabel adalah kuat dan searah, diakatakan positif.

Bila $\mathrm{r}=-1$ atau mendekati -1 , maka korelasi antara kedua variabel adalah kuat dan berlawanan arah, dikatakan negatif.

\section{Uji Determinasi}

Menurut Ghozali (2013:97) koefesien determinasi $\left(\mathrm{R}^{2}\right)$ pada intinya mengukur seberapa jauh kemampuan model dalam menerangkan variasi variabel independent. Nilai koefesien determinasi adalah nol dan satu. Nilai
$\left(\mathrm{R}^{2}\right)$ yang kecil berati kemapuan variabel independent dalam menjelaskan variasi variabel dependent sangat terbatas.

Nilai yang mendekati satu berati variabel independent memberikan hampir semua informasi yang dibutuhkan untuk memprediksi variabel dependent.

\section{Uji Normalitas}

Uji normalitas bertujuan untuk menguji apakah variabel memiliki distribusi normal atau tidak. Dalam penelitian ini digunakan uji Kolmogorof-Smirnof digunakan untuk menguji apakah variabel berasal dari distribusi yang sama .

\section{Model regresi linier sederhana}

Dalam penelitian ini menggunakan metode analisis regresi sederhana dalam menguji hipotesis. Model ini digunakan untuk mengetahui pengaruh gaya kepemimpinan terhadap kinerja karyawan. Sugiyono (2014:270) menjelaskan bahwa analisa regresi linier sederhana didasarkan pada hubungan fungsional ataupun kausal satu variabel independent dengan satu variabel dependent.

Secara umum analisis regresi pada dasarnya adalah suatu studi mengenai ketergantungan variabel 
dependent (variabel terikat) dengan satu variabel independent (variabel bebas) dengan tujuan untuk mengestimasi atau memprediksi rata-rata populasi atau nilai rata-rata variabel dependen berdasarkan nilai variabel independen yang diketahui.

\section{Uji Hipotesis}

Hipotesis adalah asumsi atau dugaan mengenai suatu hal yang dibuat untuk menjelaskan suatu hal yang sering dituntut untuk melakukan pengecekan. Sugiyono (2017:87) mendefenisikan hipotesis statistik adalah dalam perumusan hipotesis statistik, antara hipotesis nol (Ho) dan hipotesis alternatif (Ha) selalu berpasangan, bila salah satu ditolak maka yang lain pasti diterima. Sehingga keputusan yang tegas, yaitu jika Ho ditolak Ha diterima. Beberapa tahap pengujian hipotesis sebagai berikut :

\section{Uji Statistik t}

Uji ini bertujuan untuk menguji pengaruh secara parsial antara variabel bebas terhadap variabel terikat dengan mengasumsikan variabel lain adalah konstan. Hasil pengujian terhadap tstatistik adalah:
1. Jika sig $<\alpha$, t hitung $>\mathrm{t}$ tabel dan koefesien $\beta$ positif, maka hipotesis diterima.

2. Jika sig $<\alpha$, t hitung $>\mathrm{t}$ tabel dan koefesien $\beta$ negatif, maka hipotesis ditolak.

3. Jika sig $>\alpha$, thitung $<$ t tabel, maka hipotesis ditolak.

\section{KESIMPULAN}

Berdasarkan hasil dan analisis uji instrumen didapat hasil validitas dan reliabel yang signifikan. Dibuktikan dengan hasil pengujian validitas dengan hasil $r$ hitung lebih besar dari $r$ tabel $(>0,333)$.Secara keseluruhan item pertanyan tersebut valid dan dapat menjawab dugaan sementara. Serta hasil pengujian reliabel dengan hasil cronbrach alpha >0,60, dibuktikan dengan nilai cronbrach alpha hasil output spss lebih besar dari $(>0,60)$ dengan demikian variabel gaya kepemimpinan terhadap kinerja karyawan dapat dikatakan reliabel dan terpercaya sebagai alat pengukuran data dalam penelitian ini.

2. Hasil korelasi perhitungan dengan output spss versi 25 dapat disimpulkan nilai signifikansi antara kedua variabel adalah berkorelasi, 
karena nilai signifikansi yang didapatkan dalam perhitungan lebih kecil dari 0,05. Dengan Pearson Correlation yang diperoleh sebesar $0,0,744$ bernilai positif dan kuat maka hubungan kedua variabel adalah berkorelasi kuat.

3. Berdasarkan hasil pengujian hipotesis diperoleh nilai uji $\mathrm{t}$ adalah signifikan sebesar 0,000 dan nilai $t$ hitung adalah 7,018. Sesuai dengan dasar pengambilan keputusan jika nilai signifikansi lebih kecil dari pada nilai konbrach alpha (sig < 0,05) dan thitung $>\mathrm{t}$ tabel $(2,030)$ maka variabel tersebut berpengaruh positif dan secara parsial hipotesis diterima. Dan Berdasarkan hasil penelitian uji f dapat dilihat bahwa nilai $f$ bernilai positif dengan hasil 49,247ini lebih besar dari $\mathrm{f}$ tabel, ( $\mathrm{df}=$ 29), dengan nilai f tabel sebesar 4,12 dan nilai signifikansinya sebesar 0,000 lebih kecil dari 0,05. Jadi dapat disimpulkan bahwa hipotesis dalam penelitian ini secara simultan diterima dengan taraf siginifikan sangat signifikan.

\section{REFERENCES}

Ghozali (2013).Dasar-Dasar Metode Statistika Untuk Penelitian. Bandung: CV. Pustaka Setia
Imam （2015 ) Pengaruh Gaya Kepemimpinan terhadap Kinerja Karyawan pada Hotel Travellers Suites Medan Vol. 3, No. 1

Malayu, Hasibuan (2016). Menejemen Sumber Daya Manusia: Gaya Kepemimpinan Dan Motivasi Kerja,Jakarta: PT. Bumi aksara Moeheriono (2012).Kepemimpinan Yang Efektif. Yogyakarta: UGM Press

Notoatmodjo, Soekidjo (2015).

Menejemen Sumber Daya Manusia: Gaya Kepemimpinan, Motivasi Kerja, Perilaku Organisasi Dan Budaya Organisasi,Bandung: Pustaka Setia

Riniwati (2011).Teory Motivasi Dan Pengukurannya. Jakarta: Bumi Aksara

Rivai (2014).Kepemimpinan Dan Perilaku Organisasi. Jakarta: PT. Raja Grafindo Persada Ryani Dhyan Parashakti \& Dede Irfan S ( 2019 ) : Gaya kepemimpinan dan Motivasi terhadap Kinerja Karyawan SAMUDRA EKONOMI DAN BISNIS, VOL 10, NO 1 
Swanto, Sutrisno (2011). Motivasi Kepemimpinan Dan Efektifitas Kelompok. Jakarta: PT. Rineka cipta.

Sutrisno (2015).Menejemen Sumber Daya Manusia:Motivasi kerja dan perilaku kerja dalam perusahaan. Yogyakarta: Mediakom

Terry (2012).Manajemen Motivasi. Jakarta: PT. Grasindo

Thoha, Miftah (2013). Kepemimpinan Dalam Manajemen, Jakarta: PT. Raja Grafindo

Wibowo (2014). Kepemimpinan:Teori, Psikologi, Perilaku Organisasi, Aplikasi Dan Penelitian. Jakarta: PT. Raja Grafindo Persada

Farera Erlangga Dan Lince Magriasti. 2013. Pengaruh Gaya Kepemimpinan Paternalistik Terhadap Motivasi Kerja Pegawai Dinas Sosial Dan Tenaga Kerja KotaPadang.https://ejournal.unp. ac.id/index.php/humanus/article/ download/4037/3221. Di Akses Pada Tanggal 6 Desember 2019. Setiyati Sri. 2014. Pengaruh Kepemimpinan Kepala Sekolah,
Motivasi Kerja, Dan Budaya Sekolah Terhadap Kinerja Guru. https://journal.uny.ac.id/index.p hp/jptk/article/download/8931/7 305. Di Akses Pada Tanggal 21 Desember 2019.

Suhardi.2018. Pengaruh Motivasi Kerja, Kompetensi, Lingkungan Kerja Dan Kompensasi Terhadap Kinerja Karyawan PT. Asuransi Jiwa Di Kota Batam Dengan Organizational Citizenship Behavior Sebagai Variabel Intervening.

https://ejournal.kopertis10.or.id/i ndex.php/benefita/article/downl oad/3670/1440. Di Akses Pada Tanggal 26 Desember 2019.

Syahputra Roy Dan Hengki Mangiring Parulian Simarmata. 2018. Kepemimpinan, Kepuasan Kerja Dan Motivasi Terhadap Kinerja Pegawai. https://jurnal.umsu.ac.id/index.p hp/mbisnis/article/download/214 6/3090. Di Akses Pada Tanggal 26 Desember 2019. 